\title{
Adjudicating sartorial elegance from the court - the sumptuary impulse in the law of modern sports sponsorship against ambush marketing
}

\author{
Chen Wei Zhu* \\ Birmingham Law School
}

\begin{abstract}
Ambush marketing, sometimes also known as guerrilla marketing, comprises attempts to create an unauthorized association with mega-sporting events (such as the Olympic Games and the FIFA World Cup) without obtaining official sponsorship agreements. This article contends that the contemporary law of sports sponsorships against ambush marketing harbours a palpable but much-neglected sumptuary impulse, which has never before been adequately scrutinized. It shows that pre-modern sumptuary law strangely resonates with modern anti-ambush law's sumptuary obsession with the visual order of symbols and images as prestige signifiers. It also reveals an ongoing 'intellectual property' turn in the recent development of sumptuary anti-ambush law-making, whose ambition is to reify sports-derived sumptuary distinction into a thing-in-itself for nearly absolute 'property' protection. My argument is illustrated by a carefully selected number of ambush disputes including Australian Olympic Committee (AOC) v Telstra, which represents the latest development in this field of law.
\end{abstract}

Keywords: ambush marketing, sports sponsorship IP law, sumptuary code, dress code, Barton Beebe, Rule 50 of the Olympic Charter, trade marks and brands, Olympic Games

\section{INTRODUCTION}

Sumptuary law, which is conventionally regarded as an ancient and feudal relic from the distant pre-industrial past, hardly died out with the advent of modernity. Far from coming to a fatal demise ushered in by James I's repeal act of 1604, as observed by Sir William Blackstone, ${ }^{1}$ sumptuary law - as a legal form of regulating excessive expenditure on luxury products such as inordinately expensive apparel - persistently lingers

* An early draft of this article was selected to be presented at the 2016 Society of Legal Scholars conference at St Catherine's College, Oxford, where the author benefited from comments by the attendees. It has thus been substantially revised multiple times before taking its current form. The author is grateful for the speedy and constructive feedback from the anonymous QMJIP reviewers. Dr Jean Harrison kindly proofread the final draft of this article. The author is also thankful to Charmaine Lai for her unwavering support during the process of writing this article.

1. In England, Blackstone noticed that the James I's 1604 act (1 Jac. I. c. 25) discontinued all earlier sumptuary laws against excessive apparel. However, there remained one unrepealed 'antient statute', which was Edward III's mediaeval statute restraining excessive diets (10 Edw. III. St. 3). W Blackstone, Commentaries on the Laws of England, Book IV (1769) 170-71. 
on in England and elsewhere. ${ }^{2}$ Unfortunately, the continuous sumptuary impulse in the modern legal order tends to be treated as intellectually trivial or even non-existent by contemporary lawyers, as though it is domiciled in what Foucault calls 'Unthought' in modern legal thinking. ${ }^{3}$ In fact, sumptuary law is anything but a failure when encountering modernity, but it creeps into the contemporary regulatory culture so snugly that it needs to be seen as an 'intrinsic element in the formation of the modern legal order'. 4 Alan Hunt likens modern sumptuary law to a metaphorical 'butterfly' that 'can barely be imagined from the chrysalis' because it has been transfigured so much that 'the original is barely recognizable in the resultant'. 5

With this in mind, this article challenges modern law's 'Unthought' by contending that contemporary sports sponsorship law against 'ambush marketing' in megasporting events ${ }^{6}$ (such as the Olympic Games and the FIFA World Cup) harbours a palpable but much-neglected sumptuary impulse, which has never before been adequately scrutinized. Although there is a lack of a universally agreed upon definition of 'ambush marketing, ${ }^{7}$ a typical 'ambush' campaign can be broadly characterized as non-sponsors' attempts to create an unauthorized association with a mega-event without obtaining official sponsorship agreements. ${ }^{8}$ This characterization falls further into two definitional sub-categories, with one focusing on on-site ambushes known as 'intrusion' and the other on 'association' that can often happen off the field. These two sub-categories are respectively noticed in two early pioneering researches on ambush marketing. On the one hand, Meenaghan sees 'ambush marketing' as attempts to 'intrude[]' by 'deflecting attention to itself and away from the sponsor'. ${ }^{9}$ On the other hand, Sandler and Shani define ambush tactics as 'a planned effort by an

2. See, for example, R Robson, Dressing Constitutionally: Hierarchy, Sexuality, and Democracy from Our Hairstyles to Our Shoes (CUP 2013); LM Ponte, 'Echoes of the Sumptuary Impulse: Considering the Threads of Social Identity, Economic Protectionism, and Public Morality in the Proposed Design Piracy Prohibition Act' (2009)12 Vand. J. Ent. \& Tech. L. 45; C Elliott, 'Purple Pasts: Color Codification in the Ancient World' (2008) 33(1) Law \& Social Inquiry 173 (beginning with the US Supreme Court's 'sumptuary' ruling in Qualitex Co. v Jacobson Products Co. (1995) 514 U.S. 159).

3. P Goodrich, 'Signs Taken for Wonders: Community, Identity, and a History of Sumptuary Law' (1998) 23(3) Law and Social Inquiry 707, at 723. For Foucault's discussion of 'Unthought', see M Foucault, The Order of Things: An Archelogy of the Human Sciences (Routledge 2002) 351-8.

4. Goodrich, ibid 708-9.

5. A Hunt, Governance of the Consuming Passions: A History of Sumptuary Law (Palgrave Macmillan 1996) 361. For Hunt's own reflection on his intellectual journey into sumptuary law research, see A Hunt, 'Getting Marx and Foucault into Bed Together!' (2004) 31(4) Journal of Law and Society 592, 598-9.

6. For a critical analysis of what constitutes a 'mega' event, see M Müller, 'What Makes an Event a Mega-Event? Definitions and Sizes' (2015) 34(6) Leisure Studies 627-42.

7. P Johnson, Ambush Marketing and Brand Protection: Law and Practice (2nd edn, OUP 2011) 8-9.

8. See, for example, the Rio Olympic Games Organising Committee, which characterizes 'ambush marketing' as 'any intentional or unintentional attempt to create a false, unauthorised commercial association with a brand or event ...', Rio 2016 Brand Protection Guidelines: The Advertising Market and Advertisers at <https://library.olympic.org/Default/doc/SYRACUSE/ 76211/brand-protection-guidelines-advertising-market-and-advertisers-organising-committeefor-the-olympic-?.lg=en-GB> (2014, Version 2) 42.

9. T Meenaghan, 'Ambush Marketing - A Threat to Corporate Sponsorship' (1996) 38 Sloan Management Review 103, 106. 
organization to associate itself indirectly with an event in order to gain at least some of the recognition and benefits that are associated with being an official sponsor' ${ }^{10}{ }^{1}$ I will show later in this article that both 'intrusion' and 'association' are the regulatory objects governed by the modern 'sumptuary' law of sports sponsorship. ${ }^{11}$

Ambush marketing, through either 'intrusion' or 'association', threatens the exclusivity of sports sponsorships by diluting the aura of top-performing athleticism reserved for official sponsors. It reduces the semiotic power of official sponsors' brands to denote sports-related cachet or prestige available for conspicuous consumption among sports-loving consumers. As a response to this threat, anti-ambush law is introduced to re-assemble the consumption-based hierarchy of brand images for the sports sponsorship market. Historically, sumptuary law has tended to happen during turbulent historical moments - for example, in Tudor England, ${ }^{12}$ mediaeval and Renaissance Italy ${ }^{13}$ or Tokugawa Japan ${ }^{14}$ - where old status symbols became radically de-stabilized due to socio-economic changes. The rise of contemporary anti-ambush law should not be seen as an exception, because it essentially embodies a similar sumptuary desire for restoring the status of certain symbols to be privileged in a hierarchical order intended by sports organizers.

In order to critically examine anti-ambush law's sumptuary impulse in the contemporary sports sponsorship world, the rest of the article proceeds in four sections. Firstly, I use Edward III's 1363 sumptuary statute as a heuristic example of premodern sumptuary law, which I will show strangely resonates with modern sports sponsorships' sumptuary obsession with the visual order of symbols and imagery. Secondly, I distinguish two different conceptual approaches to sumptuary law in history. One focuses on curbing the conspicuous consumption of luxury goods, while the other is centred around the legal control of individuals' appearance in public. I argue that the latter's 'appearential' approach to sumptuary law is more accurate in capturing the sumptuary logic behind anti-ambush marketing law. Thirdly, I argue that modern sports sponsorship law can be even more radical in making appearential regulations than its pre-modern predecessors. This is because modern anti-ambush law does not just enjoin direct imitative use of sartorial symbols, it also attempts to prevent indirect evocation of sporting events' imagery that constitutes ambush marketing. I will reveal an 'intellectual property' (IP) turn in the recent development of sumptuary anti-ambush law-making whose ambition is to reify sports-derived sumptuary distinction for nearly absolute 'property' protection. I will also use my analysis to re-evaluate Barton Beebe's claim in his seminal 2010 Harvard Law Review article that modern sumptuary law reinvents itself in the form of IP law, ${ }^{15}$ but in the new context of sports sponsorships and ambush marketing. The final section concludes.

10. D Sandler and D Shani, 'Olympic Sponsorship vs "Ambush" Marketing: Who Gets the Gold?' (1989) 29 Journal of Advertising Research 9, 11 (emphasis added).

11. See section 4 below for my discussion of sumptuary law's two governance modes.

12. W Hooper, 'The Tudor Sumptuary Laws' (1915) 30(119) English Historical Review 433; Noel Cox, 'Tudor Sumptuary Laws and Academical Dress: An Act Against Wearing Costly Apparel 1509 and an Act for Reformation of Excess in Apparel 1533' (2006) 6 Transactions of the Burgon Society 15; Leah Kirtio, "The Inordinate Excess in Apparel": Sumptuary Legislation in Tudor England' (2011) 1(3) Constellations 17.

13. J Brundage, 'Sumptuary Laws and Prostitution in Late Medieval Italy' (1987) 13 Journal of Medieval History 343; Catherine Kovesi Killerby, Sumptuary Law in Italy 1200-1500 (OUP 2002). 14. D Shively, 'Sumptuary Regulation in Early Tokugawa Japan' (1964-65) 25 Harvard Journal of Asiatic Studies 123.

15. B Beebe, 'Intellectual Property Law and the Sumptuary Code' (2010) 123(4) HLR 809. 


\section{GOVERNING PRESTIGE SIGNIFIERS: SUMPTUARY LAW AND SPORTS SPONSORSHIP}

This section shows that pre-modern sumptuary law and contemporary sports sponsorship schemes strangely share a common desire to govern the order and the ordering of prestige signifiers (such as apparel) despite the historical distance between them. As it is neither possible nor necessary for an article of this kind to give a full historical account of the sumptuary legal order, I choose to begin with Edward III's 1363 statute as a heuristic example to give a glimpse into the way a typical pre-modern sumptuary law is conceptualized and operationalized. This is followed by a brief (revisionist) account of modern sports sponsorship schemes, which are framed as attempts to build a privately-made sumptuary order of prestige signifiers associated with sporting events.

\subsection{The Statute of 1363: a paradigm of pre-modern sumptuary law}

In the 37th year of Edward III's reign in England, a curious piece of sumptuary legislation known as Statut' de Victu et Vestitu (A Statute Concerning Diet and Apparel) of 1363 was promulgated. This 1363 sumptuary statute stands out as an extraordinary legal artefact thanks to its economistic meticulousness in sartorially dividing the people of England into eight classes according to their respective social and economic statuses. Each class is assigned a tailor-made dress code by the monarch who prescribes the type of apparel that is permitted as well as the textiles for making this apparel. This state-sanctioned dress code creates a striking visual hierarchy that allows class distinctions to be manifested through legally defined sartorial entitlements. ${ }^{16}$

Under the 1363 statute, the top social class is made up of 'Knights and Ladies' whose yearly income from land or rent exceeds 400 marks. This high echelon of society is permitted to wear anything 'at their Pleasure, except Ermins and Letuses, and Apparel of [Pearls and Stone, but only] for their Heads'. ${ }^{17}$ In stark sartorial contrast, the lowest class of the social hierarchy - including 'Carters, Ploughmen, Drivers of the Plough, Oxherds, Cowherds, Shephards' and people whose income is less than 'Forty Shillings of Goods' - is entitled to 'no Manner of Cloth' at all. Instead, they can only wear 'Blanket, and Russet' worth up to 12 pence apiece and they are also required to wear 'Girdles of Linen according to their Estate'. ${ }^{18}$

Most interestingly, the dress code for the high-income merchant class ${ }^{19}$ - whose total capital is worth more than $£ 500$ - is put in the same bracket with that of landowning esquires and gentlemen whose annual income is above $£ 100$. This means that the richest merchants may use their economic capital to leverage the legal entitlement to higher status symbols and thus spend their way into the sartorial style of the Edwardian landed gentry, who are just below the rank of 'Knights and Ladies'. The merchant class is further subdivided into two sub-classes, with the lower division

16. The 1363 law is neither the first English sumptuary legislation nor is it the last one of its kind. For the economic historical background of this legislation, see SK Silverman, 'The 1363 English Sumptuary Law: A Comparison with Fabric Prices of the Late Fourteenth Century' (MSc thesis, 2011) at <https://etd.ohiolink.edu/rws_etd/document/get/osu1322596483/inline>. 17. (1363) 37 Edw. III c.12; Statute of the Realm Vol 1(hereafter SR I) (reprinted 1963) 381. 18. (1363) 37 Edw. III c.14; SR I 381-2.

19. The merchant class also includes 'Citizens and Burgesses, Artificers, People of Handycraft', (1363) 37 Edw. III c.11; SR 381. 
owning a total capital between $£ 500$ and $£ 1000$ and the higher division owning more than $£ 1000$. The lower division is prohibited from wearing 'Cloth for their Clothing or Hosing' worth more than four and half marks and they cannot wear 'Cloth of Gold, nor Silk, nor Silver, nor no Manner of Clothing imbroidered, Ring, [Buttons,] nor owche of Gold, Ribband of Gold nor of Silver, nor nothing [of Stone] nor no manner of Furr'. The higher division is allowed more luxury clothing as they can 'take and wear Cloths of the Price of [five] Marks the whole Cloth, and Cloth of Silk and of Silver, Ribband, Girdle, and other Apparel reasonable garnished of silver'. ${ }^{20}$

The 1363 Statute represents both a paradigm case and a high-water mark of sumptuary legislation in English history regarding its sweeping scope and fastidious detail. Its obsessively economistic construction of the multi-tiered class structure manifested through apparel makes this mediaeval statute precociously 'modern' thanks to its legal technique of designating 'the dress hierarchy by fixing a sliding scale of expenditure limits' as pointed out by Hunt. ${ }^{21}$ Although the 1363 law was repealed just one year later due to its immense unpopularity, ${ }^{22}$ its demise by no means spells the end of sumptuary law in England. Its palpable sumptuary impulse continues to beget many later legislative progenies for at least another 240 years, until this line of sumptuary law of apparel petered out in the early seventeenth century.

\subsection{The sumptuary impulse of modern sports sponsorships}

So what do the 1363 sumptuary statute in the Middle Ages and contemporary sports sponsorship schemes have in common? It is often neglected that sports sponsorships, though operating in a quite different socio-economic milieu, harbour a similar sumptuary impulse to assemble a consumption-based social hierarchy through creating a relative scarcity of prestige signifiers. A key reason behind this neglect can be attributed to the different material condition where the contemporary world is situated. In the premodern world, materials that can be used as status symbols (such as furs) are naturally scarce and costly to simulate. In contrast, the contemporary era has witnessed a fast rise of advanced mimetic technologies (such as digital printing and additive manufacturing techniques) which become ever more affordable. As a result, traditional status symbols have rapidly lost their semiotic power to signify an aura of luxury because they can be easily replicated. This becomes what Beebe calls the 'Diamond Age of the sumptuary code', ${ }^{23}$ where even precious stones such as diamonds can be persuasively simulated at a relatively low cost, let alone those mass-produced consumer goods.

Against this backdrop, modern corporations are under increasing pressure to employ innovative marketing strategies to generate non-material quality attributes for their products to stand out in a cluttered market. They are motivated to launch sumptuous advertising campaigns to stimulate consumers' desire for the symbolic consumption of branded products. ${ }^{24}$ Among these marketing strategies, sports sponsorships are believed to be an effective means to boost the symbolic value of a sponsor' brands through an association with mega-sporting events. It is pointed out that

20. (1363) 37 Edw. III c.10-11; SR I 380-1.

21. Hunt, Governance of the Consuming Passions (n 5) 304.

22. (1364) $38 \mathrm{Edw}$. III, c.2; SR I, 383.

23. Beebe (n 15) 835 .

24. SJ Levy, 'Symbols for Sale' (1959) 37 Harvard Business Review 117; C Lury, Brands: The Logos of the Global Economy (Routledge 2004). 
sports sponsorships have an 'upmarketing' effect for improving the brand image of sponsors:

Sponsorship operation can allow sponsors to 'upmarket' their products or services. The purpose of product positioning is to shape consumers' beliefs with the hope consumers will ultimately differentiate the sponsor's brand from the brands of its competitors. Therefore, it is crucial to position the brand so it presents a clear and unique recognition in the mind of the consumer. ${ }^{25}$

In this light, sports sponsorships can be seen as possessing an under-noticed 'sumptuary' effect where sponsors' brands are transformed into artificially scarce prestige signifiers. They form a new type of brand-based sumptuary order where commercial sponsors (especially sportswear companies) can expect to gain a higher brand distinction against their non-sponsoring competitors. This distinction is sumptuary in nature because it contributes to the hierarchization of a saturated marketplace, where sponsors' brands are allowed to bask in the reflected aura of top-performing athleticism derived from a given mega-event. Ironically, the image of prestige produced by sports sponsorships may well be a kind of masstige ${ }^{26}$ which supplies those sports-loving consumers with an illusion of exclusivity. However, this image of masstige made for symbolic consumption is precisely what the sumptuary effect of modern sports sponsorships aims to achieve, because it is sufficient to help conspicuous consumers conduct what Veblen calls the 'invidious comparison' against other consumers due to the sharpened 'invidious distinction' ${ }^{27}$ attached to a sponsoring product.

\subsection{Sumptuary ordering in the Olympic sponsorship hierarchy}

Sports sponsorships do not just give individual consumers a sense of 'invidious distinction', they also work at the corporate level. ${ }^{28}$ They serve as a proxy for corporate sponsors' wealth by signalling their brands' masstige in a hierarchized global market. Sports sponsorships are expensive tickets to elite corporate clubs that buy a right to be associated with the sumptuous image of mega-sporting events. One of the most expensive sports sponsorship clubs is no doubt the Olympic sponsorship scheme, which prescribes a hierarchical structure according to the different level of sponsorship fees that are paid. On the top of this hierarchy is the Olympics' worldwide sponsorship programme known as TOP (The Olympic Partnership), which was initially designed by Adidas's Horst Dassler in the mid-1980s for the International Olympic Committee (IOC). ${ }^{29}$

25. A Ferrand et al., Routledge Handbook of Sports Sponsorship: Successful Strategies, trans. by PF Lanlonde and E Christopherson (Routledge 2007) 30.

26. M Silverstein and N Fiske, 'Luxury for the Masses' (2003) 81(4) Harvard Business Review 48.

27. T Veblen, The Theory of the Leisure Class: An Economic Study of Institutions (OUP 2007; first published in 1899) 23.

28. For the relation between corporate advertising and conspicuous consumption of mass consumers, see Daniel Krähmer, 'Advertising and Conspicuous Consumption' (2006) 162(4) Journal of Institutional and Theoretical Economics 661; G Patsiaouras and JA Fitchett, 'The Evolution of Conspicuous Consumption' (2012) 4(1) Journal of Historical Research in Marketing 154.

29. See RK Barney, SR Wenn and SG Martyn, Selling the Five Rings: The International Olympic Committee and the Rise of Olympic Commercialism (University of Utah Press 2004) $168-71$. 
The membership fee for the TOP club is estimated to be about $\$ 200$ million per quadrennium. ${ }^{30}$ In order to guarantee the exclusivity of TOP sponsorships, only one worldwide sponsor is allowed to sponsor one exclusive category of goods or services. ${ }^{31}$ The current TOP club (TOP IX Partners) comprises the world's 13 richest multinational corporations. The most senior member of this club is Coca-Cola, ${ }^{32}$ followed by Visa, Bridgestone, Samsung, Panasonic, Omega, Procter \& Gamble, General Electric, Dow, Atos, Intel, Toyota and Alibaba. ${ }^{33}$ Most interestingly, the Alibaba Group, a Chinese e-commerce giant founded less than a generation ago, joined as TOP's youngest sponsor in the exclusive category of 'Cloud infrastructure, Cloud Services and E-Commerce Platform Services' in 2017. ${ }^{34}$ As a nouveau riche member in this elite group, Alibaba reportedly plans to expend $\$ 600$ million in sponsorship fees on six editions of the Olympics until 2028. ${ }^{35}$ Below the TOP sponsorships, there are three lower hierarchical tiers of sponsors at the domestic levels: (i) 'Gold Partners'; (ii) 'Official Partners'; and (iii) 'Official Supporters'. The price tags for each in the 2020 Tokyo Games are respectively estimated to be $\$ 128$ million for 'Gold Partners', \$51.1 million for 'Official Partners' and \$8.5 million to \$25.5 million for 'Official Supporters'. 36

The Olympic tiered sponsorship structure is reminiscent of the mediaeval sumptuary stratification of status symbols. Corporate sponsors are not unlike those fourteenthcentury Edwardian high-income merchants, who can spend their way into the upper echelons of the sumptuary order under the 1363 statute. They are given the right to be associated with prestigious Olympic symbols just as their mediaeval counterparts (i.e., members of the rising merchant class) were given access to high-class sartorial symbols normally reserved for the landed gentry. Under Edward III's reign, the class structure was visually manifested through the hierarchization of apparel and attire mandated by the monarch. Under the Olympic sponsorship system, the stratification of sponsors is structured through the order of trade symbols known as 'brands' that are allowed to be used in juxtaposition with the Olympic brand, which comprises a host of so-called 'Olympic Properties' as detailed in the Olympic Charter. ${ }^{37}$

30. I Boudway, 'Olympic Sponsorships Are About to Get More Expensive', 28 September 2017, at <https://www.bloomberg.com/news/articles/2017-09-28/olympic-sponsorships-areabout-to-get-a-lot-more-expensive $>$.

31. For example, Coca-Cola is the TOP sponsor for the exclusive category of 'Non-alcoholic Beverages' and Panasonic for 'Audio/TV/Video Equipment'.

32. M Hepburn, 'Timeline: History of the Coca-Cola Company and the Olympic Games' at $<$ https://www.coca-cola.co.uk/stories/making-history-with-the-olympic-games $>$.

33. IOC, Olympic Marketing Fact File, 2018 Edition (2018) 11-14 at <https://stillmed.olympic. org/media/Document\%20Library/OlympicOrg/Documents/IOC-Marketing-and-BroadcastingGeneral-Files/Olympic-Marketing-Fact-File-2018.pdf>.

34. IOC, 'Olympic Partner Alibaba Group Opens New Doors to the Cloud for its first Olympic Games', 10 February 2018 at <https://www.olympic.org/news/olympic-partner-alibaba-groupopens-new-doors-to-the-cloud-for-its-first-olympic-games $>$.

35. M Ahmed, 'Alibaba to Sponsor Next 6 Olympic Games - Chinese Ecommerce Group Founded by Jack Ma Joins Elite Corporate Backers', Financial Times, 19 January 2017 at $<$ https://www.ft.com/content/b5e16726-de1e-11e6-9d7c-be108f1c1dce>.

36. P Osborne, 'Sponsors to Pay $\$ 128$ Million for Leading Package at Tokyo 2020', 19 January 2015, at <https://www.insidethegames.biz/articles/1024987/sponsors-to-pay-128-million-for-toppackage-at-tokyo-2020>.

37. Rules 7-14, Olympic Charter (September 2017). 
A more striking similarity with the 1363 sumptuary law of apparel can also be seen in modern Olympic sponsorships' sartorial power over the use of clothing items within Olympic venues. Most notably, Rule 50 of the Olympic Charter ${ }^{38}$ has been frequently invoked to combat innovative ambush marketers' use of apparel or wearable items as ambush weapons. ${ }^{39}$ This rule consecrates the Olympic brand's unassailable top position in the Olympic sumptuary order by supressing any form of advertising of non-Olympic brands within Olympic competition venues. Michael Payne, the former IOC's marketing chief, was proud of the IOC's track record of imposing sartorial sanctions against ambushers under Rule 50. For example, shortly before the 1988 Calgary Winter Games opening ceremony, 60000 Coca-Cola logos were discovered to be wrongly printed on the outside of ponchos to be distributed to spectators in the McMahon Stadium. In order to implement Rule 50's clean-venue policy, the IOC ordered all these 60000 ponchos to be turned inside out and repacked before the ceremony began. ${ }^{40}$ Similarly, before the 2000 Sydney Olympic Games, 30000 food service personnel's uniforms were found to bear the logo of the catering company Aramark 'prominently displayed on the left side of the chest'. In an attempt to protect the Olympics' official sponsor McDonald's exclusive right and implement Rule 50, an army of seamstresses were swiftly hired to sew patches onto the offending apparel to cover all the 'Aramark' logos. ${ }^{41}$

These two incidents show the IOC's tremendous sartorial power over the appearance of apparel and attire within Olympic venues for the purpose of brand protection. They also demonstrate a key difference between mediaeval sumptuary law and modern Olympic anti-ambush measures. The former is known to be poorly enforced and the actual punishment of sartorial offences proves to be difficult. ${ }^{42}$ In contrast, the modern Olympic authority is equipped with a nimbler rights enforcement mechanism for detecting and sanctioning sartorial infractions that disturb the visual order of branded images on sports fields. This contemporary sumptuary regime roughly follows a Foucauldian trajectory moving away from 'legality', which was previously imposed by the centralized monarchical power (as under Edward III's reign), to 'governmentality', ${ }^{43}$ whose governance mode is restructured by the diffused regulatory power of private actors such as the IOC. To some extent, this modern sumptuary power exercised by the Olympic authority can be more coercive than its mediaeval predecessor's, as its governance is more subtly embedded in the neo-liberal economistic logic under which modern sports sponsorships are operationalized. In the rest of the article, I will elaborate this point further by showing that the reach of modern sports sponsorships' governmentality is both broader and more ambitious than the mere governance of private consumption of luxury clothing items.

38. Rule 50, Olympic Charter, ibid.

39. See section 4.1 below for a more detailed discussion.

40. M Payne, Olympic Turnaround: How the Olympics Games Stepped Back from the Brink of Extinction to Become the World's Best Known Brand - and a Multi-Billion Dollar Global Franchise (Praeger 2006) 146.

41. Ibid 147.

42. E Baldwin, Sumptuary Legislation and Personal Regulation in England (The Johns Hopkins Press 1926).

43. M Foucault, 'Governmentality', in The Foucault Effect: Studies in Governmentality, eds G Burchell et al. (University of Chicago Press 1991) 87-104; M Dean, Governmentality: Power and Rule in Modern Society (Sage 1999); Goodrich (n 3) 709. 


\section{AMBUSH MARKETING: SUBVERTING THE SUMPTUARY ORDER}

This section reveals what makes anti-ambush marketing law a 'modern' sumptuary phenomenon. It argues that this law belongs to the law of images in general and that of sports-related brand images in particular. Modern anti-ambush law's sumptuary ambition is much more than being a law of apparel and sartorial styles, but its abiding regulatory interest should be more widely seen as covering all aspects of appearential regulations related to the control of images within and beyond sporting venues.

\section{1 'Modern' sumptuary law: two schools of thought}

What makes sumptuary law 'modern'? Why do those pre-1604 English sumptuary legislations questioned by Blackstone lose their appeal to modern legislators? How may modern anti-ambush marketing law re-invent a new sumptuary order through a visual hierarchy of branded images in relation to a mega-sporting event?

In order to answer these questions, I need to differentiate two schools of thought on sumptuary law as a unified (or at least, a loosely unified) body of law. I call the first one the 'consumption' school, which holds a narrow view of sumptuary law. It is aimed at curbing excessive consumption of what are perceived to be luxury products. The second school is called the 'appearance' school, which holds a broader view. It broadens sumptuary law's scope to cover all legal measures that govern appearance and imagery capable of signifying sumptuary distinction. I will try to show that the broad view held by the second school possesses more explanatory power to understand the modern sumptuary rationale behind the law of sports sponsorship. I will now begin with an analysis of the first school's narrow regulatory interest in conspicuous consumption as a contrast to the second school's broad perspective.

\subsubsection{The 'consumption' school}

The 'consumption' school derives its idea from the literal meaning of ancient Roman leges sumptuariae, which is the original Latin term for 'sumptuary law', which suggests that this body of law is intended to control sumptus - which literally means 'cost', 'expense' or 'expenditure' - in relation to private citizens' conspicuous consumption. The etymology of the term also forms the basis of the standard dictionary definition of 'sumptuary law', which is seen as the regulation of excessive consumption of food, dress and other signifiers of wealth. For example, the Oxford English Dictionary provides a stereotypical 'consumption'-centred view of 'sumptuary law'. It defines the adjective 'sumptuary' as '[p]ertaining to or regulating expenditure' and 'sumptuary law' as 'a law regulating expenditure, esp. with a view to restraining excess in food, dress, equipage, etc.' ${ }^{44}$

Under the Anglo-American legal tradition, the first most fervent period of sumptuary law-making against excessive consumption begins with Edward III's reign (1327-1377) and it does not come to an end until the early seventeenth century. ${ }^{45}$ Sumptuary laws in

44. OED, 'sumptuary, adj. (and n.)', OED Online (March 2018) at $<$ http://www.oed.com/ view/Entry/194039?redirectedFrom=sumptuary+law\& $>$; see also the 'sumptuary law' entry in HC Black, Black's Law Dictionary (1999, 6th edn) 1436.

45. R Robson, 'Beyond Sumptuary: Constitutionalism, Clothes, and Bodies in AngloAmerican Law' (2013) 2 British Journal of American Legal Studies 478. 
this era provide plenty of ammunition for the 'consumption' school's view of sumptuary law. Beginning in 1336, Edward III promulgated the first sumptuary statute during his reign, which was aimed at cracking down on 'the excessive and overmany sorts of costly Meats which the People of this Realm have used' ${ }^{46}$ It prohibited people from eating more than two courses 'at dinner, meal, or supper, or at any other time' during non-feast days. ${ }^{47}$ In the following year of 1337, Edward III extended his sumptuary law from food to clothing by promulgating a new statute banning the use of foreign imported cloth ${ }^{48}$ as well as furred clothes. ${ }^{49}$ This 1337 sumptuary statute is significant because it is arguably the first recorded purpose-made law of apparel in English legal history $^{50}$ and it would undergo numerous further iterations (including the 1363 Statute as mentioned in the previous section) in the following 267 years before they were all repealed by the first Stuart monarch James I in $1604 .{ }^{51}$ It is crucial to note that the 1604 repeal act by no means spells a permanent end of sumptuary law-making in Britain. ${ }^{52}$ Instead, it is merely a sign of the decline of the 'consumption'-based sumptuary law. In centuries to come, the 'consumption' school of thought on sumptuary law would only become increasingly at odds with the rising liberal laissez-faire economics. ${ }^{53}$ Free-market liberalists tend to hold a visceral hostility towards the state regulation of individuals' private spending on luxury goods. This sentiment against state-sanctioned sumptuary law has been forcefully expressed by Adam Smith:

It is the highest impertinence and presumption, therefore, in kings and ministers, to pretend to watch over the economy of private people, and to restrain their expence, either by sumptuary laws, or by prohibiting the importation of foreign luxuries. ${ }^{54}$

\subsubsection{The 'appearance' school}

In contrast to the 'consumption' school, the second school known as the 'appearance' school offers a different view about sumptuary law. It does not directly concern the legal control of inordinate expenditure or conspicuous consumption, but it shifts the sumptuary law's focus to the regulation of personal appearance. This school was spearheaded by Alan Hunt's revisionist reading of historical sumptuary law in his seminal book, Governance of the Consuming Passions. ${ }^{55}$ Hunt points out that

46. The over-consumption of expensive meats was believed to cause 'many mischiefs', and people from both upper and low classes would be equally adversely affected: 'for the great men, by these excesses, have been sore grieved, and the lesser People, who only endeavour to imitate the great ones in such sort of Meats, are much impoverished', (1336) 10 Edw. III Stat. 3; SR I, 278-9.

47. Ibid.

48. The royal family was exempted from this ban, (1337) 11 Edw. III c.2; SR I, 280.

49. The royal family and 'the Prelates, Earls, Barons, Knights, and Ladies, and People of Holy Church' were exempted from this ban, (1337) 11 Edw. III c.4; SR I, 280-81.

50. Robson (n 45) 479.

51. 1 Jac. I. c. 25 (1604); Blackstone (n 1).

52. The 1604 act was largely a compromise that resulted from the long-term constitutional struggle between English monarchs and parliament dating back to the Tudor period. Hooper (n 12) 449.

53. See for example, WS Holdsworth, 'The Importance of Adam Smith's Wealth of Nations in English Legal History' (1935) 2(4) The University of Chicago Law Review 533.

54. A Smith, The Wealth of Nations, ed. SM Soares (MetaLibri 2007, originally published 1776) 270.

55. Hunt, Governance of the Consuming Passions (n 5). 
sumptuary law is not merely about curbing conspicuous consumption, but its remit may cover 'all forms of the presentation of the self':

I will take the paradigm case of sumptuary law as being the regulation of personal appearance through rules relating to clothing, and social ceremonies associated with the presentation of the self and of economic wealth, in particular baptisms, weddings, funerals and other events in the life-cycle of individuals and kinship groups. ${ }^{56}$

The Huntian approach to sumptuary law - which is essentially synonymous with the 'appearance' school - opens up at least two new avenues for a better understanding of sumptuary law's changing morphological shape in both the pre-modern and modern ages. First, it provides a non-teleological explanatory framework for exploring sumptuary legislation as a legal domain specializing in regulating the social order of appearance or imagery. ${ }^{57}$ It sets itself apart from earlier sumptuary legal scholarship, which tends to be more anxious about the 'motives' or 'purposes' intended by sumptuary legislators. ${ }^{58}$ Second, the 'appearance' school has the advantage of understanding sumptuary law not merely as a pre-industrial legacy from the past, but also as a response to modernity's unabated obsession with the ordering of images in society. One of the most notable sites of modern appearential regulations is professional dress codes at work. Its broad scope ranges from contemporary lawyers' attire (such as robes, gowns and wigs) ${ }^{59}$ to female receptionists' high-heeled stilettos ${ }^{60}$ to NBA basketball players' 'business casual' dress code. ${ }^{61}$ These contemporary sumptuary codes of professional attire hold little interest in curbing conspicuous consumption, but they are all appearential rules attempting to regiment professionals into a look or image that is acceptable and presentable in their respective circles. For example, the London-based PricewaterhouseCoopers (PwC) had an appearance policy in 2016 that required female 'customer-facing' staff members to wear high heels no lower than two inches. Nicola Thorp, a female receptionist from Hackney, refused to abide by this rule and was sacked from the position straightaway. ${ }^{62}$ PwC's high heels policy serves as an interesting counterpoint to Edward IV's 1463 statute forbidding people from wearing long-toed shoes whose 'pikes' are longer than

56. Ibid 7 (emphasis added).

57. Ibid.

58. The teleological approach is characteristic of Baldwin's 1926 study of sumptuary law - see Baldwin (n 42) - which has influenced later sumptuary law researches such as that by Leah Kirtio (n 12).

59. The legal profession around the world, to a large degree, is still visually distinguished by its unique code of professional attire that connotes the order of law. See, for example, S O'Neill, 'Why Are Judges' Robes Black?' (2001) 7 Massachusetts Legal History: A Journal of the Supreme Judicial Court Historical Society 119; CM Yablon, 'Judicial Drag: An Essay on Wigs, Robes and Legal Change' (1995) 5 Wisconsin Law Review 1129-53; R McQueen, 'Of Wigs and Gowns: A Short History of Legal and Judicial Dress in Australia' (1999) 16 Law in Context: A Socio-Legal Journal 31.

60. BBC, 'London Receptionist "Sent Home for Not Wearing Heels", 11 May 2016 at <http:// www.bbc.co.uk/news/uk-england-london-36264229>.

61. MG McDonald and J Toglia, 'Dressed for Success? The NBA's Dress Code, the Workings of Whiteness and Corporate Culture' (2010) 13(6) Sport in Society 970.

62. C Lytton, 'Temp Worker Sent Home Unpaid from PwC Job "for Not Wearing High Heels", 11 May 2016 at <http://www.telegraph.co.uk/women/work/temp-worker-sent-homefrom-pwc-job-for-not-wearing-high-heels/ $>$. For a discussion of discriminatory dress codes in the workplace, see S Middlemiss, 'Not What to Wear? Employers' Liability for Dress Codes?' (2018) 18(1) International Journal of Discrimination and the Law 40. 
two inches. ${ }^{63}$ Note that Edward IV's law is a typical 'consumption'-school sumptuary law attempting to restrict certain excessive consumptive behaviour, while PwC's appearance policy is anything but a measure of controlling conspicuous consumption. On the contrary, the latter mandates a conspicuously sexualized female look symbolized by the image of high-heeled shoes. Portico, the agency for Nicola Thorp, explained that the rationale behind PwC's appearance guidelines was to 'ensure customer-facing staff are consistently well presented and positively represent [PwC]'s brand and image'. ${ }^{64}$ This explanation may be unwittingly seen as a perfect soundbite for the 'appearance' school's understanding of modern sumptuary law that fetishizes branded images in the contemporary corporate world.

In fact, the pre-modern sumptus-restricting sumptuary law under the 'consumption' school can also be seen as a specific type of appearential law under the 'appearance' school. This is because the latter is conceptually spacious enough to cover all forms of sumptuary regulations regardless of the excessiveness of consumption in ancient and contemporary ages. In this vein, Goodrich points out that all sumptuary laws ultimately belong to the same family called 'law of images':

Understood as a crucial part of the law of images, and equally as a dimension of the legal construction of the symbolic order, the regulation of appearances can be reinterpreted as a key component in the identity of those 'imagined communities' .... What the history of sumptuary regulation most enduringly transmits is a sense of the dependence of law upon the construction and maintenance of images of propriety, reason, and authority. ${ }^{65}$

For this reason, I favour the 'appearance' approach over the 'consumption' approach in understanding the sumptuary nature of modern sports sponsorships and anti'ambush marketing' law in the contemporary context. In the following sub-section, I will delve into more details about the concept and practice of 'ambush marketing', which can be seen as a struggle to transfer the 'image' of a given mega-sporting event to an ambusher without an official sponsorship agreement. In this sense, antiambush regulations also fall under Goodrich's 'law of images', because they are a special type of sumptuary law that governs the transfer of brand images in relation to sporting events.

\subsection{Re-defining 'ambush marketing' from the appearential regulation perspective}

With the idea of sumptuary law being a type of appearential regulation of images in mind, I propose to radically re-define 'ambush marketing' as a group of activities that intend to subvert the sumptuary order of branded images governed by sports sponsorship schemes. This redefinition needs to be understood in a historical context, where 'ambush marketing' first arises as non-sponsors' reactions to sporting event organizers' efforts to sharpen the sumptuary distinction of official sponsors' brand images through much more exclusively controlled sponsorship deals. Unlike the term 'sumptuary law', 'ambush marketing' does not have a provenance from the ancient Greco-Roman world, but its beginning was often dated back to as late as

63. (1463) 3 Edw. IV. c. 5; SR II, 401. This 1463 sumptuary law is a direct progeny of Edward's III 1363 statute, as mentioned before, though it was promulgated a century later.

64. BBC (n 60).

65. Goodrich (n 3) 724. 
the 1980s when mega-sporting events backed by big sponsorship money began to take off financially. The phenomenon was first observed during the 1984 Los Angeles (LA) Olympic Games, which was the first commercially successful Olympic Games supported by a sponsorship programme designed by its organizing committee's president Peter Ueberroth. ${ }^{66}$ Ueberroth's less-is-more sponsorship philosophy allowed him to significantly limit the number of official sponsors to about 30 companies. ${ }^{67}$ (This is a much smaller number than the over 600 sponsors for the 1976 Montreal Games.) This move significantly sharpens the brand distinction for each of its sponsors who can be exclusively associated with the LA Games' image. However, Ueberroth's sponsorship scheme also created an unintended consequence for the 1984 Games: a large number of corporations - which ended up failing to become official Olympic sponsors - were forced to develop alterative advertising strategies. Logically, one of such strategies is to launch 'ambush marketing' campaigns to cultivate an unauthorized association with the Olympic Games when an aspirational company fails to become an official sponsor.

During the 1984 LA Games, the official sponsor Fuji was reportedly the first company to be 'ambushed', with the ambusher being its corporate nemesis Kodak. The latter, unable to secure a sponsorship agreement, managed to become a minor technology sponsor of the broadcaster ABC and USA's track and field team. This ambush was a success because the ambusher ended up gaining more brand exposure than the official sponsor among television audiences. ${ }^{68}$ It also demonstrates how an ambush attack may subvert the official appearential order of brands intended by a sporting event organizer. This ambush results in the image of the ambusher Kodak's brand appearing closer to the Olympic games than that of the real sponsor Fuji's brand. The maintenance of the intended appearential order of branded images is exactly the site where anti-ambush sumptuary law is needed, but this law was clearly absent in the year 1984. Four years later, Kodak outbid Fuji to become one of the nine official worldwide TOP sponsors for the 1988 Seoul Games. This allowed the former ambusher to officially reverse the previous Olympic sumptuary order of brands. Interestingly, Fuji did not hesitate to launch a retaliating ambush attack at Kodak, and it did so by sponsoring the US swimming team. ${ }^{69}$

Since these two Fuji/Kodak 'ambush' incidents, ambush marketing cases have been repeatedly identified in mega-sporting events over the following years. It becomes increasingly hard to find common attributes for these ambush campaigns, which only become more and more imaginative and creative. Scholars have responded by developing an increasingly sophisticated typology to categorize and understand this phenomenon. Since Meenaghan's 1998 paper that divides ambush marketing into five types, ${ }^{70}$ newer typologies of ambush activities have kept emerging, until

66. Barney et al. (n 29) 193-8.

67. RN Davis, 'Ambushing the Olympic Games' (1996) 3 Villanova Sports \& Ent. L.J. 423, at $424-5$.

68. Campaign, 'History of Advertising: No 134: Kodak's 1984 Olympics Ads', 28 May 2015, at <https://www.campaignlive.co.uk/article/history-advertising-no-134-kodaks-1984-olympicsads/1348519>.

69. 'Kodak Beats Fuji in Bid for Sponsor of Olympics', 19 October 1994 at <http://articles. orlandosentinel.com/1994-10-19/business/9410190351_1_kodak-room-for-growth-1998winter-olympics $>$.

70. T Meenaghan, 'Ambush Marketing: Corporate Strategy and Consumer Reaction' (1998) 15 Psychology \& Marketing 305. 
Nufer's taxonomy reached a total of 21 types in his 2013 monograph. ${ }^{71}$ This trend of classificatory scholarship goes in the direction of a decreased degree of theoretical abstraction but an increased degree of factual specification. It may also risk blunting Occam's razor by being extremely detailed on specific types of ambush marketing stunts only at the expense of analytical depth.

Without the burden of over-taxonomizing 'ambush marketing', this article benefits from the insight of the 'appearance' school of sumptuary law to recalibrate this perplexing phenomenon. It re-defines the essence of 'ambush marketing' as a tactic that subverts the sumptuary order dictated by the visual hierarchy of branded images in association with a mega-sporting event. This sumptuary order is decreed by sports sponsorships, whose success is dependent upon the authorized transfer of image from an event to its official sponsors. Gwinner defines an authorized 'image transfer' as 'the image of the event ... being transferred to the image of the sponsoring brand when an individual connects information about the event's attributes, event's benefits, or attitudes about the event with the brand in his/her memory'. ${ }^{72}$ In this light, a successful image transfer helps sponsors to increase their product differentiation in a cluttered marketplace.

Conversely, ambush marketing reduces official sponsors' brand distinction by hijacking their intended image transfer. The competition between official sponsors and ambush marketers is essentially a battle to gain higher brand position in a given sumptuary order of branded imagery. As a response, anti-ambush marketing legal measures are created to stabilize the brand sumptuary order by protecting official sponsors' sports-related brand image from being appropriated or diluted by nonsponsors' ambush attacks. In other words, anti-ambush laws are essentially appearential regulations that prevent the brand image of non-sponsors from appearing to have a connection with a given sporting event. They specialize in regulating the unauthorized transfer of branded images from an event to non-sponsors and thus ultimately belong to a subset of a sumptuary law of images. The following section further delves into two distinct appearential governance modes employed by antiambush laws to prevent unauthorized image transfer by non-sponsoring third parties.

\section{MORE THAN DRESS CODE: TWO GOVERNANCE MODES}

Ambush marketing often does not just involve direct imitative use of mega-sporting events' symbols or brands. ${ }^{73}$ It can be staged in a way to indirectly evoke the image of a mega-sporting event. This evocative use is most likely to make spectators

71. G Nufer, Ambush Marketing in Sports: Theory and Practice (Routledge 2013). Between Meenaghan and Nufer there are other classificatory schemes to capture new types of ambush marketing stunts. See, for example, J Crompton, 'Sponsorship Ambushing in Sport' (2004) 9(1) Managing Leisure 1; S Chadwick and N Burton, 'The Evolving Sophistication of Ambush Marketing: A Typology of Strategies' (2011) 53(6) Thunderbird International Business Review 709.

72. K Gwinner, 'Image Transfer in Global Sport Sponsorship - Theoretical Support and Boundary Conditions' in J Amis and BT Cornwell (eds), Global Sport Sponsorship (Berg 2005) 165.

73. The direct use of an event's insignia can be a matter of straightforward trade mark infringement. See for example, Boston Athletic Association v Sullivan 867 F.2d 22 (1st Cir. 1989) (concerning the use of 'Boston Marathon' on T-shirts). 
create a mental association with a given event but not necessarily be confused. ${ }^{74}$ With this in mind, this section analyses two sumptuary governance modes employed by anti-ambush laws. The first is the sartorial governance mode that tackles ambush campaigns involving the use of unauthorized apparel. The second governance mode takes shape in what can be broadly categorized as 'intellectual property' (IP) law. The IP governance mode goes beyond those anti-ambush dress codes by covering non-sartorial ambush stunts that make ambushers' brands appear to have an association with a sporting event. Most interestingly, anti-ambush regulations under this governance mode develop a unique right of association, which is analogous to the anti-'dilution' branch of IP law. This will eventually lead me to re-evaluate Barton Beebe's incisive observation that some areas of IP law have been recently used as a proxy regime for stabilizing contemporary sumptuary codes. I will now begin with the first governance mode.

\subsection{Dress to distress: ambush through unauthorized apparel}

Anti-ambush law's sartorial governance mode imposes sumptuary power on what can be worn within a sporting venue. It makes modern anti-ambush laws bear a prima facie resemblance to pre-modern laws of apparel and attire, which are primarily a set of sartorial rules to create sumptuary distinction. Two related incidents from two FIFA World Cup matches eloquently show the power of the sartorial governance mode against ambushes through unauthorized apparel. The first incident happened in the 2006 Germany World Cup, where thousands of Dutch football fans were ordered to remove their orange lion-tailed lederhosen, or 'leeuwenhosen' ${ }^{75}$ before they were allowed entry into a Stuttgart stadium. This 'leeuwenhosen' ban was invoked because this attire worn by Dutch spectators was purveyed by the Dutch brewery Bavaria, which was not FIFA's official sponsor. ${ }^{76}$ The FIFA regarded this as an ambush on the exclusive right of its official sponsor Anheuser Busch's Budweiser beer, and its rights enforcement team did not hesitate to confiscate these 'illicit' costumes. This action was taken on the grounds that Dutch fans' lederhosen contravened the Terms and Conditions on football-match tickets, whose Rule 10 stated that 'advertising, commercial, political or religious articles of all types including banners, symbols and flyers' were 'inadmissible'. ${ }^{77}$

This incident was followed by a similar but subtler sartorial ambush four years later, when the FIFA World Cup moved to South Africa. During the Holland-Denmark match, 36 female spectators were ejected from the stadium for wearing orangecoloured mini-dresses. This orange attire was suspected to be part of a ploy again masterminded by the Bavaria brewery. Unlike the orange leeuwenhosen - which were

74. National Hockey League v Pepsi Cola Canada Ltd (1992) 42 CPR (3d) 390; New Zealand and Commonwealth Games Assn v Telecom New Zealand and Saatchi and Saatchi [1996] F.S.R. 757.

75. 'Leeuwenhosen' is a portmanteau term combining the German word for 'lion' and the Dutch word for 'pants'. It also alludes to the 2006 FIFA World Cup's mascot 'Goleo VI' the lion.

76. A pair of the promotional lederhosen cost $€ 7.95$ when purchasing 12 tins of Bavaria beer. Osborne Clarke, 'Caught with its Pants Down?', 31 July 2006 at $<$ http://marketinglaw.osborneclarke.com/media-and-ip/caught-with-its-pants-down/>.

77. G Nufer, 'Ambush Marketing in Sports: An Attack on Sponsorship or Innovative Marketing?' (2016) 6(4) Sport, Business and Management: An International Journal 476, at 485. 
emblazoned with Bavaria's logo in the previous incident - these mini-dresses bore no conspicuous marks visible to the public in the stadium let alone to the broadcast audience. Two of these Dutch women were arrested and made to appear in a local magistrate's court facing charges for flouting South Africa's Merchandise Marks Act (MMA) 1941, whose 2002 amended version $^{78}$ was designed to tackle ambush marketing directly. ${ }^{79}$

Despite the above two sensational ambush attacks, it is relatively rare for antiambush measures to be enforced directly against spectators. ${ }^{80}$ In contrast, athletic participants wearing offending apparel can often face more severe sumptuary sanctions from anti-ambush sartorial regulations. For example, during the 1996 Atlanta Olympic Games, the Costa Rican gold-medallist swimmer Claudia Poll was discovered to be wearing a swimming cap bearing three tiny offending logos respectively representing Pepsi-Cola, Costa Rican TV and an unidentifiable brand - none of which was an official Olympic sponsor. On the victory podium, Poll revealed, under her Olympic uniform, a Pepsi-branded T-shirt. ${ }^{81}$ The athlete was immediately banned from wearing the ambushing headgear in any future competition and she was almost stripped of her gold medal. ${ }^{82}$ The Costa Rican Olympic Committee argued that the Pepsi T-shirt was unintentionally picked by Poll in a hurry, but this defence was unsuccessful and they eventually issued a formal apology. ${ }^{83}$

The Poll incident shows the sartorial power that the IOC can wield on athletes' wearable items within Olympic venues. This power emanates from Rule 50 of the Olympic Charter, which spawned a set of elaborate dress codes known as Guidelines Regarding Authorised Identifications (hereafter ID Guidelines). These dress codes are designed to combat ambush marketing based on Rule 50's 'cleanvenue' clause, which prohibits any type of advertisement (even including that of official sponsors) 'in and above the stadia, venues and other competition areas which are considered as part of the Olympic sites'. ${ }^{84}$ This rule is unique to the Olympics as most other mega-sporting events do allow in-stadia advertising. It is noteworthy that Rule 50's no-advertising policy is deliberately designed as an Olympic marketing strategy, because the clean-venue image is conceived to be part of the Olympic branded image for attracting commercial sponsorships. There is no hiding that advertising-free Olympic venues increase the Olympics' commercial value or brand equity, though

78. Merchandise Marks Amendment Act 2002.

79. Section $15 \mathrm{a}(2)$ of MMA stipulates that 'no person may use a trade mark in relation to [a designated] event in a manner which is calculated to achieve publicity for that trade mark and thereby to derive special promotional benefit from the event, without the prior authority of the organiser of such event'.

80. For example, unlike South Africa's MMA, New Zealand's anti-ambush law explicitly exempts a spectator ('a member of the public') from wearing 'articles of clothing (including shoes) or other personal items' that bear advertising marks in an event venue (s 22(b)(i), Major Event Management Act (2007)). Similarly, Regulation 8 of the London Olympic Games and Paralympic Games (Advertising and Street Trading \&c.) (England) Regulations 2011 tolerates an individual wearing 'advertising attire' unless this individual 'knows or has reasonable cause to believe that he or she is participating in an ambush marketing campaign'.

81. LA Times, 'Always Coca-Cola? Not for Swimmer', Los Angeles Times, 4 August 1996, at $<$ http://articles.latimes.com/1996-08-04/news/ss-31340_1_pepsi-logo>.

82. Poll only escaped this sanction because Coca-Cola did not wish to alienate the Costa Rican market by pressing the IOC to punish Costa Rica's first gold medallist. Payne (n 40) 148.

83. Ibid 149.

84. Rule 50.1, Olympic Charter (n 37). 
this argument may sound counterintuitive at first glance. Coca-Cola's Steven Jones, in a letter to the IOC, makes the Olympics' strategy abundantly clear:

A clean field of play is an Olympic equity ... One of [the IOC's] core assets. The field of play is an important branding space that [the IOC] own[s]. Own every inch of it! Sharing [the Olympics'] branding space dilutes the Olympic brand. ${ }^{85}$

It is a common mistake to think of Rule 50 as merely a clean-venue policy. What is often neglected is Rule 50's 'sumptuary' clause, hidden under its Bye-law 1, which mandates appearential rules about what brands and symbols are allowed to appear on athletic participants' apparel and personal items:

No form of publicity or propaganda, commercial or otherwise, may appear on persons, on sportswear, accessories or, more generally, on any article of clothing or equipment whatsoever worn or used by all competitors, team officials, other team personnel and all other participants in the Olympic Games, except for the identification ... of the manufacturer of the article or equipment concerned, provided that such identification shall not be marked conspicuously for advertising purposes. $^{86}$

Empowered by this 'sumptuary' clause, the IOC has made a set of implementation guidelines for authorizing non-Olympic marks and symbols (known as 'identifications') appearing on athletes' attire and personal items. These guidelines are highly detailed and technical in dictating the exact appearance of the authorized 'identifications'. Their sartorial governance technique is composed of four basic parameters, covering: (1) the conspicuousness; (2) the type; (3) the place; and (4) the frequency of those non-Olympic marks that can appear on athletes' apparel and wearable items. First, identifications need to be modest and they are not allowed to be 'marked conspicuously for advertising purposes' according to Rule 50. The conspicuousness of an identification is mainly measured by the size of a certain mark. As a general rule, identifications of manufacturers on clothing shall not exceed $30 \mathrm{~cm}^{2}$ and product technology identifications not be bigger than $10 \mathrm{~cm}^{2}$. When elastic fabrics such as LYCRA $^{\circledR}$ are used, the size of identifications need to be measured when stretched. ${ }^{87}$ Second, not all types of identifications are allowed. The types that are permitted to appear on athletes' apparel include manufacturers' marks, national Olympic committees' emblems, international sports federations' identifications, emblems and wordmarks of a particular edition of the Games (e.g. 'PyeongChang 2018') and product technology identifications (i.e. names of fabric technologies on clothing items). The third parameter deals with the place of identifications on apparel and personal items. Just to take athletes' one-piece bodysuits as an example: one manufacturer's identification and one product technology identification are permitted to be displayed 'above the waist and below the waist' ${ }^{88}$ The final parameter determines the frequency of identifications. It normally allows one identification per item. Some items are allowed no identification at all as they must be unbranded. Such items include

85. S Jones, 'Letter to the IOC', quoted in Payne (n 40) 162.

86. IOC, Olympic Charter (n 37) (emphasis added).

87. IOC, Guidelines Regarding Authorised Identifications (Rio Games, July 2015) 9, at $<$ https://library.olympic.org/Default/doc/SYRACUSE/162100/guidelines-regarding-authorisedidentifications-games-of-the-xxxi-olympiad-rio-2016-international-ol?_lg=en-GB>.

88. IOC, Guidelines Regarding Authorised Identifications (PyeongChang Games, March 2017) 29, at <https://www.isu.org/docman-documents-links-2/2018-pyeongchang/ioc-guides-1/ 15406-ioc-rule-50-pyeongchang-en-v2-revised/file>. 
'headphones, water bottles, umbrellas, towels, bandages, contact lenses, earplugs, mouth guards and nose clips'. ${ }^{89}$ Note this list is a non-exhaustive one and it may 'be amended and completed from time to time by the IOC' .90

These four parameters of the Olympic appearential law may be further refined when applied to a specific sport, which is subject to rules given by this sport's governing federation. For example, on top of the IOC's general $30 \mathrm{~cm}^{2}$-limitation rule for the size of manufacturers' identifications, the International Association of Athletics Federations (IAAF) further requires the lettering of these identifications on T-shirt, singlets or vests not to 'exceed $4 \mathrm{~cm}$ in height and the total identification shall not exceed $5 \mathrm{~cm}$ in height' and no identification is permitted on under garments. ${ }^{91}$

It is not difficult to see that the appearential regulations under the above Rule 50's Identification Guidelines are fastidiously detailed and technical. (See Table 1, which summarizes the key sartorial rules under Rule 50.) They represent the ultimate modern sumptuary regulation of apparel reinvented in the new context of sports sponsorships. The guidelines prescribe a strictly enforced visual order of athletic sartorial appearance that can be mapped onto a hierarchy of branded images allowed to be visible on sports fields. They put Olympic insignias at the very top of the sumptuary order and supress other brands into minor visual prominence. By doing so, Rule 50's sartorial governance allows the Olympic brand to realize its full commercial value for attracting sponsorship revenues and, at the same time, restrains ambush marketing campaigns that dare to challenge the prescribed sumptuary branding order within Olympic competition venues.

\subsection{Reifying sumptuary distinction: the 'intellectual property' turn}

Although Rule 50 embodies significant sartorial power within the areas designated as official Olympic venues, it is completely powerless against ambush marketing campaigns taking place outside these venues. In order to counter off-the-venue ambushes, there is an emerging trend where anti-ambush sumptuary law is gradually undertaking what I call the 'intellectual property' (IP) turn, whose governance mode aims to reify sports-related sumptuary distinction into a thing-in-itself or a 'sponsorship property'. ${ }^{92}$ In other words, the IP governance mode's ambition is to turn the relative sumptuary distinction derived from sports events into an absolute property right regardless of consumers' confusion. This observation coincides with Barton Beebe's general claim that modern sumptuary law has recently taken a new but rather 'eccentric' form disguised in IP law:

... we are increasingly investing intellectual property law with, and forcing the law to adapt

to, a new purpose. This purpose is to preserve and stabilize our modern sumptuary code in

89. IOC (n 37); this rule has indeed been implemented. For example, Michael Phelps was forced to cover a pair of branded headphones during the Rio Olympic Games. C Gaines, 'Michael Phelps was Forced to Cover the Logo of his Beats Headphones and He Did a Lackluster Job with the Tape', 8 August 2016, at <http://uk.businessinsider.com/michaelphelps-beats-olympics-headphones-2016-8>.

90. IOC (n 37) 9.

91. IOC (n 87) 45.

92. T Meenaghan, 'Ambush Marketing - a Threat to Corporate Sponsorship' (1996) 38 Sloan Management Review 103 at 106. 
Table 1 Rule 50's sumptuary impulse: sartorial governance of athletes' attire and wearable items under Olympic guidelines of authorized identifications (Rio and PyeongChang Games, 2016-2018)

\begin{tabular}{|c|c|c|c|}
\hline Regulated Items & $\begin{array}{l}\text { Manufacturer } \\
\text { Identification }\end{array}$ & Frequency & Size \\
\hline Clothing & Yes & 1 & $\operatorname{Max} 30 \mathrm{~cm}^{2}$ \\
\hline Footwear & Yes & $\begin{array}{l}* \text { As in } \\
\text { retail }\end{array}$ & *As in retail \\
\hline Sports Equipment & Yes & $\begin{array}{l}* \text { As in } \\
\text { retail }\end{array}$ & $\begin{array}{l}\text { (A) Equipment supplied by the } \\
\text { NOC or athlete: marks must be } \\
\text { non-conspicuous and consistent } \\
\text { with retail items* } \\
\text { (B) OCOG-supplied equipment: no } \\
\text { bigger than } 10 \% \text { of the surface area } \\
\quad\left(\max 60 \mathrm{~cm}^{2}\right)\end{array}$ \\
\hline Socks & Yes & 1 & $\operatorname{Max} 10 \mathrm{~cm}^{2}$ \\
\hline Headgear & Yes & 1 & $\operatorname{Max} 10 \mathrm{~cm}^{2}$ \\
\hline Eyewear & Yes & $\begin{array}{l}* \text { As in } \\
\text { retail }\end{array}$ & *As in retail \\
\hline Armbands & Yes & 1 & $6 \mathrm{~cm}^{2}$ \\
\hline Gloves & Yes & 1 & $8 \mathrm{~cm}^{2}$ \\
\hline Bag & Yes & 1 & $\begin{array}{l}\text { No bigger than } 10 \% \text { of the surface } \\
\text { area }\left(\max 60 \mathrm{~cm}^{2}\right)\end{array}$ \\
\hline Scarves (for Winter Games) & Yes & 1 & Max $6 \mathrm{~cm}^{2}$ \\
\hline $\begin{array}{l}\text { Unbranded items (head- } \\
\text { phones, water bottles, } \\
\text { umbrellas, towels, bandages, } \\
\text { contact lenses, earplugs, } \\
\text { mouth guards and nose clips, } \\
\text { etc.) }\end{array}$ & No & 0 & N/A \\
\hline
\end{tabular}

Note: *Identifications on these items need to be consistent with those on products sold to retail consumers six months prior to the Olympic Games.

Source: Compiled by the author by collating information from two Identification Guidelines respectively for the 2016 Rio Games and the 2018 PyeongChang Games (IOC (n 87) \& (n 88)).

the face of emerging social and technological conditions that threaten its viability and that intellectual property law is uniquely well-suited to address. ${ }^{93}$

Although anti-ambush law does not seem to be immediately on the radar of Beebe's 2010 article, I believe there can be a great benefit to extending Beebe's insight to the legal protection of brand distinction derived from sports sponsorship. This is because anti-ambush law's IP governance mode seems to offer a more radical, pure and comprehensive form of sumptuary appearential law than the sartorial governance mode in regulating branded imagery. In particular, the IP mode attempts to cover all types of associational marketing activities happening either within or outside a sports venue. Its ambition is to regulate the very psychological raw materials of brand distinction,

93. Beebe (n 15) 814 . 
which is made of spectator-consumers' mental association ${ }^{94}$ with - but not necessarily their confusion about - a sporting event's symbols and imagery. This attempt takes modern sumptuary law well beyond a simple sartorial matter of dress codes.

The IP governance mode in sports sponsorship has been recently buttressed by the global proliferation of sui generis legislation against ambush marketing since the 2000 Sydney Olympic Games. ${ }^{95}$ These legislative acts are noted for their ambition to create the broadest possible 'right of association', which confers an almost absolute property right in the sumptuary distinction derived from mega-sporting events. The London Olympic Games and Paralympic Games Act 2006 (London Act 2006) stands out as one of the most daring attempts to forge such an associational right, ${ }^{96}$ making it possible to punish ambushers for appropriating or free-riding on Olympic Games' images and thus subverting the Olympic sumptuary order. In particular, the now-lapsed London Act 2006 creates a so-called 'London Olympic association right' (LOAR), which consists of 'exclusive rights in relation to the use of any representation (of any kind) in a manner likely to suggest to the public that there is an association between the London Olympics and - (a) goods or services, or (b) a person who provides goods or services' ${ }^{97}$ This 'association' right closely approximates to an absolute property right under the IP governance mode, because it does not depend on a representation to confuse or mislead consumers, ${ }^{98}$ but merely a likelihood to 'suggest' a connection with the London Games would make this representation actionable. This LOAR-type association right is not an isolated phenomenon, but its cognates can be found in other jurisdictions. For example, New Zealand's Major Event Management Act (MEMA) 2007 stipulates a similar association right with almost identical wording. ${ }^{99}$ It enjoins 'any representation in a way likely to suggest to a reasonable person that there is an association between the major event and - (a) goods or services; or (b) a brand of goods or services; or (c) a person who provides goods or services'. ${ }^{100}$

94. G Franzen and M Bouwman, The Mental World of Brands: Mind, Memory and Brand Success (NTC Publications 2001) 144.

95. Australian legislations, including the Sydney 2000 Games (Indicia and Images) Protection Act 1996 and the Sydney 2000 Games (Indicia and Images) Protection Amendment Act 1997, are said to 'set a benchmark for preventing ambush marketing'. Johnson (n 7) 16.

96. M James and G Osborn, 'Guilty by Association: Olympic Law and the IP Effect' (2013) 2 IPQ 97 at 108.

97. London Act 2006, para 1(1) of Sched 4 (emphasis added).

98. T Scassa, 'Ambush Marketing and the Right of Association: Clamping Down on References to That Big Event with All the Athletes in a Couple of Years' (2011) 25 Journal of Sport Management 354, at 360.

99. It is worth noting that the MEMA 2007 does not just intend to cover only those 'Mega Events' but also 'Major Events'. 'Mega Events' attract 'primarily international participants, usually including New Zealanders' and an 'international audience', with 'extensive international media coverage' and 'significant and widespread benefits within New Zealand', while 'Major Events' attract a 'significant proportion of international participants' and a 'New Zealand and international audience' with 'significant international media coverage' and 'high level of benefits to wider New Zealand'. See New Zealand Government, 'Definition' at <http://www.majorevents.govt.nz/new-zealand-major-events/ definition>. Section 7(4) of the MEMA further specifies a set of criteria for determining what constitutes a 'Major Event', though it has never been made clear whether these criteria should be applied accumulatively or alternatively under a subjective or object test. L Longdin, 'Public Law Solutions to Private Law Problems: Major Event Regulation Subverts IP's Internal Balance' 2009 (4)10 Journal of Intellectual Property Law \& Practice 726 at 731.

100. MEMA 2007, s 10(1) (emphasis added). 
In particular, the legislative text retains the phrase 'likely to suggest', which does not require consumers to be confused or misled. This clearly signals MEMA's determination to confer absolute protection of sumptuary distinction on a major event organizer. The London Act and MEMA's attempt to airbrush consumers' confusion out of the equation has also crept into official Olympic brand protection guides. For example, the guide for the 2020 Tokyo Olympic Games expresses its willingness to clamp down on 'ambush marketing' activities that comprise 'the misappropriation of images associated with the Olympic and Paralympic Games' (emphasis added) on top of any direct use of Olympic properties or representations. ${ }^{101}$ This indicates that the Tokyo Olympic anti-ambush guide is also retrofitted into the IP governance mode for reifying Olympic sumptuary distinction based on misappropriation but not consumer confusion. All these developments testify to the actualization of the equivalent of the 'IP effect' as theorized by Carty ${ }^{102}$ in anti-ambush marketing law without developing a standalone tort of misappropriation or unfair competition ${ }^{103}$ for reifying the sumptuary distinction conferred upon Olympic organizers and official sponsors.

\subsection{AOC v Telstra: reining in the sumptuary impulse}

It is crucial to note that anti-ambush law's turn to the IP governance mode is highly selective. It only chooses to incorporate the 'sumptuary' side of IP, but it tends to disregard IP law's 'progressive' side for promoting innovation and encouraging socially progressive memetic technologies. Beebe points out that the sumptuary side of IP law emerges as 'a strange, inverted version of the progressive side' 104 of the modern IP law, which often tolerates dilutive copying activities that reduce the sumptuary distinction of luxury consumer goods (such as Louis Vuitton handbags). The progressive IP mode refuses to stretch itself to protect those luxury products' socially conservative 'authentic' image in the contemporary sumptuary order. Beebe observes that 'the phenomena of dilution and inauthenticity attest to the socially progressive, even liberatory potential of our mimetic technologies to render obsolete, by flooding it with copies, our system of consumption-based social differentiation'. ${ }^{105}$

Unlike IP law, anti-ambush law currently lacks a progressive wing in its jurisprudence. Its turn to the IP governance mode is incomplete and skewed towards the conservation of the sumptuary order prescribed by a given sports sponsorship scheme. Its overzealousness in preventing any associative activities only amplifies the propertyness of event organizers' and sponsors' sumptuary rights. It leads to the reification of their sumptuary distinction in the prescribed visual hierarchy of branded images, but it fails to heed the balance between right-holders and third parties (who may just conduct otherwise perfectly legitimate marketing campaigns) in a free marketplace.

My normative argument in this article is a call for ambush marketing laws to make a fully balanced turn to the IP governance mode by incorporating the progressive side

101. The liability from misappropriation will arise regardless of 'whether or not the act was carried out intentionally'. The Tokyo Organising Committee of the Olympic and Paralympic Games, Brand Protection - Tokyo 2020 Games (Ver. 3.2, September 2016) at <https:// tokyo2020.jp/en/copyright/data/brand-protection-EN.pdf p.11>.

102. H Carty, 'The Common Law and the Quest for the IP Effect' (2007) IPQ 237, 239.

103. M James and G Osborn (n 96) 108.

104. Beebe (n 15) 817.

105. Ibid. 
of modern IP law. Although existing court rulings that deal with ambush marketing disputes in common-law jurisdictions are limited in number, ${ }^{106}$ they have so far consistently resisted the temptation of conferring absolute property rights to event organizers and official sponsors' sumptuary distinction. This has been achieved through calibrating the legality of ambush marketing around the question as to whether the reasonable consumer may get misled or confused by ambushers' campaigns. Without repeating much discussed earlier ambush marketing cases such as NHL v PepsiCola ${ }^{107}$ and New Zealand and Commonwealth Games Association v Telecom, ${ }^{108}$ my analysis focuses on the 2016 Australian court ruling in Australian Olympic Committee $(A O C) v$ Telstra ${ }^{109}$ which represents the latest development in this line of case law.

In this case, the plaintiff AOC is the owner and custodian of relevant Olympic properties under Australia's Olympic Insignia Protection Act (OIPA) 1987. The telecommunication giant Telstra was a sponsor of the AOC and the Australian national team until 2012 when the official sponsorship was taken up by Telstra's competitor Optus Mobile Pty Ltd. Telstra then opted to become the technology partner with the Olympic telecaster the Seven Network in Australia. Shortly prior to the 2016 Rio Games, Telstra released a barrage of advertising campaigns consisting of 34 items, all of which alluded to Olympic sports. These 34 items can be grouped into seven categories, covering: (1) TV commercials; (2) advertisements promoting Samsung mobile phones; (3) videos for third-party websites; (4) retail catalogues; (5) an authentication 'landing page'; (6) retail or point of sale materials; and (7) Telstra's 'Keeping in Touch' emails and related digital materials. ${ }^{110}$ The AOC accused all of Telstra's advertisements (except Telstra's Samsung TV commercials) of breaching section 36 of the OIPA:

(1) A person, other than the AOC, must not use a protected olympic expression for commercial purposes.

(2) Subsection (1) does not apply to the use by a person of a protected olympic expression if:

(a) the person is a licensed user; and

(b) the protected olympic expression is an expression that the person is licensed to use; and

(c) that use is in accordance with the terms and conditions of the licence.

Telstra's own marketing brief shows that they were keen to subvert the sumptuary order of Olympic sponsorships, but they were also careful not to use Olympic expressions such as 'Olympics', 'Games', 'Rio', 'Gold', etc. ${ }^{111}$ Telstra's intention was clear that they wanted to have their image associated with the Olympic movement. Their

106. In fact, it is rare to have a claim enforced directly under sui generis anti-ambush laws around the world and the number of reported cases in this regard is very low. The Telstra case largely concerns the legality of (mis-)appropriating relevant Olympic insignias and this is more akin to claims under generic trade mark law than those under sui generis anti-ambush laws.

107. (1992) 42 CPR (3d) 390. See also, S McKelvey, 'NHL v. Pepsi-Cola Canada, Uh-huh! Legal Parameters of Sport Ambush Marketing' (1992) 10(3) The Entertainment and Sports Lawyer 5 .

108. [1996] F.S.R. 757; see also Longdin (n 99) at 733.

109. [2016] FCA 857.

110. Ibid para 27.

111. Ibid para 25. 
aim was to sharpen their brand distinction by launching Olympic-themed advertising without being an official sponsor:

Telstra wanted to be associated in some way with the Olympics: it wanted to create an overarching 'brand idea' and 'platform that brings to life Telstra's brand positioning of "empowering people to thrive in the connected world" through the context of sports and the Olympic [G]ames' ... Telstra well understood that, because it was not a sponsor, there were limits to what it could say or imply. ... Telstra deliberately set about implying something which it knew it could not lawfully imply. It is fairly clear, however, that Telstra wished to push the envelope as far as it could. ${ }^{112}$

There is little doubt that Telstra's intensive Olympic-themed advertising campaigns fall under the concept of 'ambush marketing' that the Olympic movement is keen to crack down on. However, Justice Wigney is reluctant to follow the Olympic authority's rhetoric, but he simply dismisses the term 'ambush marketing' as a 'distraction'. ${ }^{113}$ Without taking for granted the AOC's property entitlement to the Olympic aura, Wigney's ruling chooses to adopt a consumer-oriented test which asks whether Telstra's campaigns would suggest to 'a reasonable person' that the company was a 'sponsor of' or 'the provider of sponsorship-like support for' ${ }^{114}$ the Olympic movement in Australia. It is important to see that the Telstra court relies on consumers' perception rather than the event organizer's property entitlement against so-called 'ambush marketing'. Wigney is adamant about the crucial role of the 'reasonable person' test for adjudicating a dispute like this:

At the end of the day the statutory test is quite clear. It is simply a matter for the Court to make a factual finding concerning what the relevant application of the Olympic expression would, in context and in all the relevant circumstances, suggest to a reasonable person. The question of what would be suggested to a 'reasonable' person necessarily involves a value or normative judgment about which there may well be legitimate differences of opinion. That is particularly so given that the question of what may or may not be suggested by a combination of images and words, and in some cases sounds, is inherently impressionistic. ${ }^{15}$

After sifting through all the seven categories of Telstra's marketing and promotion materials, the court is convinced that the defendant is merely a technology partner with the Seven Network and section 36 of the OIPA has not been contravened. In short, there is no suggestion 'to a reasonable person, that Telstra is or was a sponsor of, or is or was the provider of, sponsorship-like support to any relevant Olympic body'. ${ }^{116}$

The Telstra case reminds us that the IP governance mode also contains a progressive side, which can be employed to rein in the rapid reification of sports-derived sumptuary distinction in sports sponsorships. In other words, an organizer may not be entitled to own unconditionally the whole spectacle or the aura surrounding an event. The progressive IP mode can prevent the organizer from claiming an absolute

112. Ibid para 98.

113. Ibid para 82.

114. Olympic Insignia Protection Act 1987, s 30(2)(c).

115. FCA (n 109) para.82.

116. Ibid para 124. It is also worth noting that Wigney's first-instance ruling was unsuccessfully appealed to the Full Federal Court, which found no errors in the primary judge's ruling. [2017] FCAFC 165. 
property right in the sumptuary distinction derived from a given event. The Telstra ruling resonates strongly with the 1937 Australian ruling in Victoria Park Racing and Recreation Grounds Co Ltd v Taylor, where the plaintiff was denied 'property in spectacle' surrounding the event in dispute. ${ }^{117}$ It also lends support to those proponents of ambush marketing such as Jerry Welsh, who strongly argues against official sponsors' monopoly of the 'entire thematic space' around a mega-sporting event. ${ }^{118}$ In short, the Telstra ruling shows the possibility of using a progressive IP doctrine to balance out the sumptuary impulse of sports sponsorship that strives for absolute protection regardless of consumer confusion.

In summary, this final section surveys two governance modes of anti-ambush law. The first is administered through athletic dress codes decreed by sporting governing bodies such as the IOC, while the second is achieved through a turn to the sumptuary side of IP governance mode but fails to heed IP law's progressive side. It is thus argued that future anti-ambush legislation needs to incorporate the progressive wing of IP into its legal reasoning, and this has already been signalled by the recent Australian ruling in AOC v Telstra, which affirms the use of the hypothetical 'reasonable person' in determining the legality of ambush marketing campaigns. It is highly likely that ambush marketing can be a legitimate associative marketing strategy when the 'reasonable person' is not confused about a certain sponsorship link. In this situation, no legal redress is needed or warranted. Thus, Philip Johnson points out that 'where [an ambush] campaign is not against the law or any code of practice and so no legal or regulatory action can be taken, it must be accepted for what it is: a clever marketing strategy about which nothing can be done'. ${ }^{119}$

\section{CONCLUSION}

Scholars have long been puzzled and fascinated by the rise and fall of sumptuary regulations in history. Sumptuary law is like the fabled but clichéd Schrodinger's cat, which is perceived to be both 'dead' and 'alive' at the same time. Sumptuary law is 'dead' in the sense that it is no longer regarded as appropriate for liberal states to regulate private citizens' consumptive behaviour. On the other hand, sumptuary law is still alive and kicking through its renewed life as a general law regulating appearance and imagery. This article finds that the modern law of sports sponsorships against ambush marketing is precisely the legal sphere where sumptuary law finds a regenerated discursive forum for prolonging its shelf life as a type of appearential law. It shows that ambush marketing threatens to subvert the sumptuary order of branded images governed by sports sponsorship schemes, whose sumptuary impulse resonates strongly with pre-modern sumptuary law's obsession with the visual hierarchy of prestige-signifying sartorial symbols. The modern sumptuary anti-ambush law is distinguished by its two modes of governance. The first mode uses sartorial regulations of athletic attire (such as Rule 50 of the Olympic Charter), which bear a prima facie resemblance to pre-modern sumptuary laws of apparel. The second mode turns to

117. [1937] 58 CLR 479 at 496.

118. J Welsh, 'Ambush Marketing: What It Is and What It Isn't' (2002) at <http://welshmktg. com/WMA_ambushmktg.pdf $>$.

119. Johnson (n 7) 24. 
modern 'intellectual property' law, which possesses an aspiration to reify sumptuary distinction into a thing-in-itself to be owned by event organizers and official sponsors. This IP governance mode represents a more adventurous and radical form of sumptuary law, because it does not just enjoin direct imitative use of sartorial symbols within sports venues, but it also covers indirect evocation of sporting events' images beyond designated sporting sites. In other words, anti-ambush sumptuary law is much more than a matter of athletic dress codes; its sumptuary impulse compels it to regulate the whole visual hierarchy of branded images in a given sumptuary order prescribed by sports sponsorships. 